\title{
USE OF BIOFERTILIZER TO ENHANCE YIELD OF PAK CHOI (BRASSICA RAPA L.) ON A HYDROPONIC SYSTEM
}

\author{
Mieke Rochimi Setiawati ${ }^{1}$, Rifka Suci ${ }^{2}$, Reginawanti Hindersah ${ }^{1}$, \\ Pudjawati Suryatmana ${ }^{1}$ and Betty Natalie Fitriatin ${ }^{1}$ \\ ${ }^{1}$ Soil Science Department, Agriculture Faculty of Universitas Padjadjaran, Indonesia. \\ ${ }^{2}$ Undergraduate student, Soil Science Department, Agriculture Faculty of Universitas Padjadjaran, Indonesia
}

https://doi.org/10.35410/IJAEB.2020.5533

\begin{abstract}
Hydroponic Nutrient Film Technique (NFT) is one of the innovations in crop cultivation that can increase the production both quantitively and qualitatively. The use of inorganic element in nutrient solutions could not be eliminated, because it is the only source of nutrients for plants. The addition of biofertilizer, especially endophytic bacteria is expected to reduce the use of inorganic element to sustainable agriculture. The objective of study was to determine the best combination of inorganic and biofertilizers that could increase the yield of pak choi plant in NFT hydroponics. This study has been conducted at the Soil Biology Laboratory of the Agriculture Faculty, Universitas Padjadjaran. Design of study used a Randomized Block Design (RBD) and four replications with six treatments combination of ammonium nitrate Inorganic Fertilizer (IF) and Biofertilizer (BF), that are 57,1\% IF + 42,9\% BF; $28,6 \% \mathrm{IF}+71,4 \% \mathrm{BF}$; and $14,3 \% \mathrm{IF}+$ $85,7 \% \mathrm{BF}$ along with one control treatment that is $100 \% \mathrm{IF}$. The result of this study indicates that treatment of $14,3 \% \mathrm{IF}+85,7 \% \mathrm{BF}$ could be used as the best recommendation in the formulation NFT hydroponic nutrient solutions because it could increase the yield of pak choi plants.
\end{abstract}

Keywords: NFT hydroponic, biofertilizer, pak choi.

\section{INTRODUCTION}

Pak choi is increasingly popular among Indonesians because it has complete nutrient and good for health. It contains protein, lipid, carbohydrates, Ca, P, Fe, Vit. A, B, C, E, and K, for addition it could prevent cancer, hypertension, heart disease, and digestive problems (Rosdiana, 2015). Pak choi's high interest is inversely proportional to its availability in the market. Fluctuations in productivity and the length of the supply chain have caused the uneven availability of pak choi in all regions of Indonesia.

One effort to overcome this issue is by hydroponic cultivation. Hydroponic systems can be carried out on non-agricultural land and reduced the risk of crop failure due to attack by pests, floods, drought, and weeds thus it could produce better productivity in quantity and quality. The NFT Hydroponics focuses on nutrient supply in the form of a flow of inorganic nutrient solution as deep as $3 \mathrm{~mm}$. The use of inorganic fertilizers could not be left behind, because it is the only 
Vol. 5, No. 04; 2020

ISSN: $2456-8643$

source of nutrition for plants, although its use in the long term can harm the environment. The addition of a consortium of biofertilizers to nutrient solutions, especially Diazotroph endophytic bacteria could reduce the use of inorganic fertilizers.

Diazotroph endophytic bacteria will create associations with plants and provide $\mathrm{N}$ accumulation in plants through a fixation process. According to Muthukumarasamy et al. (2005), endophytic bacteria that associated with sugar cane plants were able to fix $\mathrm{N}_{2}$ in the air and provide almost half the needs of N plants. Furthermore, the study of Setiawati et al (2007) described the use of endophytic bacteria combined with Pseudomonas sp. able to substitute N fertilizer up to 50\% and increase the dry weight of rice to $25,41 \%$.

The flow of nutrient solution in NFT hydroponics will carry endophytic bacteria through the root of plants and into the tissue through the epidermis. According to Purwanto et al. (2014), endophytic bacteria can enter the plant tissue generally through the roots, but the other parts exposed to direct air such as flower, stem, leaf (trough the stomata) and cotyledons, can also be an entry point for endophytic bacteria. The process of transporting endophytic bacteria in plant tissue utilizes intercellular of vascular systems (Reinhold et al., 2015). The process of $\mathrm{N}_{2}$ fixation in plant tissue by endophytic bacteria can occur when aerobic respiration is accelerated and the amount of oxygen entering is limited to activating the nitrogenase enzyme. The result of it can be distributed to all plant tissues through xylem and phloem transport vessels. (Reinhold et al., 2015).

Endophytic bacteria can also act as bio-stimulant agent because they are able to secrete phytohormones which can stimulate plant growth. Inoculants of endophytic bacteria in biofertilizer can produce phytohormones such as auxin, cytokinin, and gibberellin and produce metabolite compounds such as siderophore, ammonia, and antibiotics that can stimulate plant growth (Setiyowati, 2011).

The potential possessed by endophytic bacteria can be used as a substitute for inorganic fertilizers in the NFT hydroponic nutrient solution of pak choi plants. Herlianti et al. (2018) stated that the addition of biofertilizers to hydroponic nutrient solutions can increase the wet weight of pak choi plants and reduce the use of inorganic fertilizers by up to 50\%.

This study was conducted to determine the best combination of inorganic fertilizers with biofertilizers in the NFT hydroponic system pak choi plants so that it is expected to increase the growth and the fresh weight of pak choi plants.

\section{MATERIALS AND METHODS}

This study was conducted from November 2018 to April 2019 at the Laboratory of Soil Biology and Controlled Culture Laboratory Faculty of Agriculture, Padjadjaran University. The seeds of the plant use pak choi of the Flamingo variety. The nutrient solution used was a special formulation that adjusted to the needs of pak choi plant. The treatment of inorganic fertilizer in the form of ammonium nitrate $\left(\mathrm{NH}_{4} \mathrm{NO}_{3}\right)$ and biofertilizer Bion-Up, the product of Universitas Padjadjaran, consists of isolates Azotobacter sp., Azospirillum sp., nitrogen-fixing endophytic bacteria, and phosphate solubilizing bacteria.

The research method was carried out experimentally using Randomized Block Design (RBD) consisting of four treatments in combination of Inorganic Fertilizer (IF) and Biofertilizer (BF) that were $100 \mathrm{~mL} \mathrm{IF} \mathrm{(57.1 \% )} \mathrm{+} 75 \mathrm{~mL} \mathrm{BF} \mathrm{(42.9 \% );} 50 \mathrm{~mL} \mathrm{IF} \mathrm{(28.6 \% )} \mathrm{+} 125 \mathrm{~mL}$ BF (71.4\%); 
and $25 \mathrm{~mL}$ IF $(14.3 \%)+150 \mathrm{~mL}$ BF (85.7\%) also control treatment that was $150 \mathrm{~mL}$ IF (100\%). Each treatment was repeated six times so that 24 units were obtained.

Pak choi's nursery was conducted at the Controlled Culture Laboratory using rockwool media. Pak choi plants aged 14 days after the seedlings that have two new leaves are transferred to the NFT hydroponic installation. Measurement of Electric Conductivity (EC) value of nutrient solution and plant height is carried out at four Weeks After Plant (WAP). The end of four WAP pak choi plants have begun to be harvested and the fresh weight of the plant was weighed.

Data from the observations were analysed statistically using the SPSS 21 program. Testing the effect of treatment factors was carried out by the F test. If there is a significant effect, Duncan's New Multiple Range Test was carried out on level $95 \%$.

\section{RESULTS AND DISCUSSION}

\section{EC Nutrition Solution}

The results of the statistic analysis show that all treatments have EC values that are still in the condition of growing pak choi plants. Midmore (2015) states that the EC value that most suitable for pak choi growth is from $1.5-2 \mathrm{mS} / \mathrm{cm}$.

Table 1. Combination Effect of Inorganic Fertilizer and Biofertilizers on EC Values

\begin{tabular}{|c|c|c|}
\hline \multicolumn{2}{|c|}{ Treatment } & $\begin{array}{c}\text { EC value at } 4 \mathrm{WAP} \\
(\mathrm{mS} / \mathrm{cm})\end{array}$ \\
\hline $\mathrm{A}$ & $100 \%$ IF & $1.72 \mathrm{a}$ \\
\hline B & $57.1 \% \mathrm{IF}+42.9 \% \mathrm{BF}$ & $1.76 \mathrm{a}$ \\
\hline $\mathrm{C}$ & $28.6 \% \mathrm{IF}+71.4 \% \mathrm{BF}$ & $1.84 \mathrm{~b}$ \\
\hline & $14.3 \% \mathrm{IF}+85.7 \% \mathrm{BF}$ & $1.89 \mathrm{~b}$ \\
\hline
\end{tabular}

Note: Numeric followed by the same letters were non-significant on $95 \%$ Duncan's New Multiple Range Test.

EC measurements were conducted to determine the effect of the combination of treatment concentrations and the ability of plants to absorb nutrients to the ion content in nutrient solutions. This can be described in the value of electrical conductivity in EC meter devices. Changes in the EC value are directly proportional to the addition of elements in the nutrient solution, the more solute the higher the EC value produced. The addition of nutrient and microorganisms in solution would increase the number of solids dissolved in the solution so that it can increase the EC value. Sonneveld and Voogt (2009) state that the optimal EC is crop specific, and depends on environmental conditions. Higher EC hinders nutrient uptake by increasing the osmotic pressure of the nutrient solution, wastes nutrients, and the increases discharged of nutrients in to the environment, resulting in environmental pollution. Lower EC may severely affect plant health and yield. Samarakoon et al. (2006) found the best EC of the nutrient solution was $1.4 \mathrm{dS} \mathrm{m}^{-1}$ for lettuce under tropical greenhouse conditions $\left(38.5^{\circ} \mathrm{C}\right)$. Raising the $\mathrm{EC}$ to $2 \mathrm{dS} \mathrm{m} \mathrm{m}^{-1} \mathrm{did}$ not significantly increase leaf growth and yield. Fallovo et al. (2009) who reported that increasing the EC of the nutrient solution from 0.3 to $3.6 \mathrm{dS} \mathrm{m}^{-1}$ decreases the soluble sugar content of leafy 
Vol. 5, No. 04; 2020

ISSN: 2456-8643

lettuce. A high respiration rate of tissue vegetable in high EC treatment may reduce sugar content.

\section{Plant height}

Analysis of plant height at 4 WAP showed that all treatments gave significantly different results. Treatment A produces the lowest plant height with $8.29 \mathrm{~cm}$ and the highest treatment D with $11.11 \mathrm{~cm}$.

Table 2. Combination Effect of Inorganic Fertilizer and Biofertilizers on Plant Height

\begin{tabular}{|c|c|}
\hline Treatment & $\begin{array}{l}\text { Plant Height } \\
4 \text { WAP }(\mathrm{cm})\end{array}$ \\
\hline $100 \% \mathrm{IF}$ & $8.29 \mathrm{a}$ \\
\hline $57.1 \% \mathrm{IF}+42.9 \% \mathrm{BF}$ & $8.97 \mathrm{~b}$ \\
\hline $28.6 \% \mathrm{IF}+71.4 \% \mathrm{BF}$ & $10.56 \mathrm{c}$ \\
\hline D $\quad 14.3 \% \mathrm{IF}+85.7 \% \mathrm{BF}$ & $11.11 \mathrm{~d}$ \\
\hline
\end{tabular}

Note: Numeric followed by the same letters were non-significant on $95 \%$ Duncan's New Multiple Range Test.

The results showed that even with a hydroponic system, the higher the concentration of biofertilizer given could increase the growth of pak choi plants. This is in line with the research of Kleiber et al. (2013) who reported the addition of consortium biofertilizers to hydroponic cultivation systems were able to increase plant height, leaf number, leaf surface area, and fresh weight of lettuce plants.

The high input of biofertilizer, especially nitrogen fixing bacteria in treatment $\mathrm{D}$ is able to increase nitrogen accumulation in plants through $\mathrm{N}$-fixation mechanism. Nitrogen can be used by plant cells to compile protoplasm in photosynthesis and form new cells to increase plant height. Maathuis (2009) said that $\mathrm{N}$ affects organ construction, physiological characteristics, and substance synthesis as well as their distribution, which in turn affects rice yield and quality. Bernier (2011) reported that $\mathrm{N}$ is the main component of protein, and all types of enzymes are mainly composed of proteins, nucleic acid, nucleotides, coenzymes, phospholipids, and cytokinin's contain $\mathrm{N}$.

Nitrogen fixingendophytic bacteria not only provide additional $\mathrm{N}$ for plants but also can stimulate plant growth through its mechanism as a bio stimulant agent. The N-fix endophytic bacteria can produce indole acetic acid (IAA) which is an auxin group phytohormone that can function in extending cells and organs. Their exert several beneficial effects on host plants, such as nitrogen fixation, stimulation of plant growth, and induction of resistance to plants pathogens (Hung and Annapurna, 2004). Endophytes also promote the growth of plants, especially through secretion of plant growth regulators; e.g. indole-acetic acid, via phosphate-solubilizing activity, by supplying biologically fixed nitrogen. In addition, endophytic bacteria supply essential vitamins to plants (Rodoles et al., 1993). The increased shoot growth and tillering promote by production of auxin-like compounds. Other effects of endophytes infection on the host plant include modification of root morphology, enhanced uptake of minerals and alteration of nitrogen accumulation and metabolism (Stoltzfus et al., 1997; Bandara et al., 2006). 
Vol. 5, No. 04; 2020

ISSN: $2456-8643$

\section{Fresh Weight}

Treatments with the adding of biofertilizers gave the plant's fresh weight greater than inorganic fertilizer treatment (control).

Table 3. Combination Effect of Inorganic Fertilizer and Biofertilizers on Pak choi's Fresh Weight

\begin{tabular}{|c|c|}
\hline Treatment & $\begin{array}{c}\text { Average Weight } \\
(\mathrm{g})\end{array}$ \\
\hline A $100 \%$ IF & $51.89 \mathrm{a}$ \\
\hline B $57.1 \% \mathrm{IF}+42.9 \% \mathrm{BF}$ & $61.12 \mathrm{~b}$ \\
\hline C $28.6 \% \mathrm{IF}+71.4 \% \mathrm{BF}$ & $63.29 \mathrm{~b}$ \\
\hline D $14.3 \% \mathrm{IF}+85.7 \% \mathrm{BF}$ & $70.53 \mathrm{c}$ \\
\hline
\end{tabular}

Note: Numeric followed by the same letters were non-significant on $95 \%$ Duncan's New Multiple Range Test.

The difference in fresh weight between control and the treatment added with biofertilizers indicates that the provision of biofertilizers can increase plant growth, one of which is fresh weight. This result is in line with the research of Wang et al. (2014) which states that the inoculation of endophytic bacteria in rice plants with hydroponic systems is able to colonize roots and increase root morphology, canopy weight, and grain.

Treatment A was significantly different from all other treatments and produced the lowest fresh weight of $51.89 \mathrm{~g}$. The low weight of treatment A can occur because of the high input of inorganic chemicals in hydroponic nutrient solutions. The high inorganic content in plant roots and the bacterial environment can reduce nutrient absorption by roots and bacterial performance in biofertilizers. Kher (2016) explains that the level of osmosis that is too high in nutrient solutions can make plant cells plasmolysis and bacterial cells crenation.

The D treatment (14.3\% IF + 85.7\% BF) produced the highest fresh weight of the pak choi plant, which was $70.53 \mathrm{~g}$. This indicates that this concentration is the best combination in producing fresh weights of pak choi plant in NFT hydroponics. Kandel et al. (2017) state that sufficient inorganic content in nutrient solutions can optimize the N-fixing mechanism and other nutrient dissolution by bacteria. The high beneficial microbes contained in treatment $\mathrm{D}$ can increase the secretion of phytohormones in plants so as to stimulate growth and increase the fresh weight of pak choi plant (Knoth, 2014).

\section{CONCLUSION}

Based on the results of the research conducted conclusions can be taken as follows:

1. The application of inorganic and consortium biofertilizers has a significant effect on increasing plant height, EC value and fresh weight of pak choi plants with the NFT hydroponic system.

2. Nutrient solutions containing $14.3 \%$ inorganic fertilizers and $85.7 \%$ consortium biofertilizers are the best combination in increasing plant height, EC value and fresh weight of pak choi plants with NFT hydroponic system and able to reduce the use of inorganic fertilizers up to 85.7\%. 
Vol. 5, No. 04; 2020

ISSN: $2456-8643$

\section{ACKNOWLEDGEMENTS}

Research supported by Priority Research of DRPMI Universitas Padjadjaran as part of the activities of Soil Biology Laboratory at Soil Science Department, Universitas Padjadjaran. West Java, Indonesia.

\section{REFERENCES}

Bandara WMM, Seneviratne G, and Kulasooriya SA. 2011. Interactions among endophytic bacteria and fungi: effect and potentials. J. Biosci. 2006;31:645-650.

Bernier, G. 2011. My favourite flowering image: the role of cytokinin as a flowering signal. J. Exp. Bot. 64, 5795e5799.

Fallovo C., Rouphael Y., Rea E., Battistelli A., and Colla G. 2009. Nutrient solution concentration and growing season affect yield and quality of Lactuca sativa L. var. acephala in floating raft culture. J Sci Food Agric. 89: 1682-1689.

Herlianti, A.M., Setiawati M.R. and Hindersah R. 2018. Effect of Biofertilizers and Inorganic Fertilizers on Endophytic Bacteria Population, Chlorophyll Content, and Pak coy (Brassica rapa L.) Plants on NFT Hydroponics. Jurnal Agrin Vol. 22 (1) [in Indonesia]

Hung PQ, Annapurna K. 2004. Isolation and characterization of endophytic bacteria in soybean (Glycine sp.). Omonrice 2004; 12:92-101.

Jie, Z., Yanyan, W., ying, F., dan Lingli, L. 2014. Improved Plant Growth and Zn Accumulation in Grains of Rice (Oryza sativa L.) by Inoculation of Endophyte Microbes Isolated from a $\mathrm{Zn}$ Hyper accumulator, Sedumal fredii H. Journal of Agricultural and Food Chemistry. vol. 62: 1783-1791.

Kandel, S., L., Pierre, M., J., dan Sharon, L., D. 2017. Bacterial Endophyte Colonization and Distribution within Plants Journal Microorganisms, 5, 77.

Kher, Sudheer. 2016. Isolation and Identification of Bacteria. Publication. DOI: 10.13140/RG.2.1.2724.2640.

Kleiber, T., Justyna, S., and Maciej, B. 2013. Effect of Nutrient Solution Effective Microorganisms (EM-A), and Assimilation Illumination of Plants on the Induction of The Growth of Lettuce (Lattuca sativa L.) in Hydroponic Cultivation. Acta Agrobotanica. Vol. 66 (1) 2013: 27-38.

Knoth, J.L.; Kim, S.; Ettl, G.J.; Doty, S.L. 2014. Biological nitrogen fixation and biomass accumulation within poplar clones as a result of inoculations with diazotrophic endophyte consortia. New Phytol. 201, 599-609.

Maathuis, F.J., 2009. Physiological functions of mineral macronutrients. Curr. Opin. Plant Biol. $12,250 \mathrm{e} 258$. 
Midmore, D.J. 2015. Principal of tropical horticulture. Central Queesland University, Australia. University of Reading, UK.

Muthukumarasamy R., Cleenwerck I., Revathi G., Vadivelu M., Janssens D., Hoste B., Gum K.U., Park K., Son C.Y., Sa T., Caballero-Mellado J. 2005. Natural association of Glucono acetobacter diazotrophicus and diazotrophic Acetobacter peroxydans with wetland rice. Syst. Appl. Microbiol. 28:277-286.

Reinhold-Hurek, B., Bünger, W., Burbano, C.S., Sabale, M., and Hurek, T. 2015. Roots shaping their microbiome: global hotspots for microbial activity. Annu. Rev. Phytopathol. 53, 403-424. doi: 10.1146/annurev-phyto-082712-102342.

Rosdiana. 2015. The growth of pak coy after rabbit urine fertilizer application. Jurnal Matematika, Saint, dan Teknologi, Vol. 6 (1):1-9. [in Indonesia]

Rodoles B., Salmeron V., Martinez-Toledo M.V., Gonzalez-Lepz J. 1993. Production of vitamins by Azospirillum brazilense in chemically-defined media. Plant Soil. 153:97-101.

Samarakoon U.C., Weerasinghe P.A., Weerakkody A.P. 2006. Effect of Electrical Conductivity [EC] of the Nutrient Solution on Nutrient Uptake, Growth and Yield of Leaf Lettuce (Lactuca sativa L.) in Stationary Culture. Trop. Agric. Res. 18: 13-21.

Setiawati R.S., Suryatmana P., and Hudaya R. 2007. The Increasing of plant N-content and Upland Rice Yield due to N-Fixing Endophytic Bacteria and N Fertilizer Application on Saline Soils. Jurnal Himpunan Mahasiswa Pascasarjana Maluku (HMPM). Vol.3(1). [in Indonesia]

Sonneveld C., Voogt W. 2009. Plant Nutrition of Greenhouse Crops, Springer, ISBN 9048125316, New York, U.S.A.

Stoltzfus J.R., So R., Malarvithi P.P., Ladha J.K., de Bruijn F.J. 1997. Isolation of endophytic bacteria from rice and assessment of their potential for supplying rice with biologically fixed nitrogen. Plant and Soil. 194:25-36 